\title{
PERCEPTION OF FACTORS OF ENTREPRENEURSHIP \\ DEVELOPMENT IN VOJVODINA'S SUSTAINABLE TOURISM BY \\ VARIOUS BUSINESS ACTORS
}

\author{
Iva Škrbić ${ }^{1}$, Milan Nešićn ${ }^{2}$ Ivana Mišković3 , Srđan Milošević ${ }^{4}$ \\ *Corresponding author E-mail: srdjan.milosevic@tims.edu.rs
}

\begin{abstract}
A R T I C LE I N F O
A B S T R A C T

Review Article

The purpose of the study is to defining and assessment of

Received: 12 November 2019

Accepted: 02 December 2019

doi:10.5937/ekoPolj1904143S

UDC 005.961:[338.48:502.131.1

the impact of the determinants affecting the development of entrepreneurship in Vojvodina's sustainable tourism. The empirical part of the study was conducted using the Survey method. The basic research instrument was a questionnaire. Its construct was based on the factor

Keywords:

Entrepreneurship, Tourism, Sustainable development, Vojvodina

JEL: Q01, 018, Z32, I33 models of entrepreneurship, amended and adapted with item entries which can be deemed correspondent with particularities of the tourism environment of the AP of Vojvodina. The results indicate that the factors of Education and Partnership are the determinants with the strongest influence on the development of entrepreneurship in Vojvodina's sustainable tourism. Factors such as education and partnership are rated with the highest impact. Partnership, education, and cooperation between all interested stakeholders are a prerequisite for sustainable tourism in Vojvodina.
\end{abstract}

(C) 2019 EA. All rights reserved.

\section{Introduction}

Interest in entrepreneurship in tourism appears is the context of strengthening of public debate and attention paid to entrepreneurship and its role in the national, regional and local development (Page \& Ateljevic, 2009). During the previous two decades,

1 Iva Škrbić, Ph.D, assistant professor, Educons University, Faculty of Sport and Tourism, Radnička 30a, 21000 Novi Sad, +38121530633, E-mail: iva.skrbic@tims.edu.rs, ORCID ID 0000-0001-6539-9225

2 Milan Nešić, Ph.D, full professor, Educons University, Faculty of Sport and Tourism, Radnička 30a, 21000 Novi Sad, +38121530633, E-mail: milan.nesic@tims.edu.rs, ORCID ID 0000-0002-5097-5653

3 Ivana Mišković, Ph.D, assistant professor, Educons University, Faculty of Sport and Tourism, Radnička 30a, 21000 Novi Sad, +38121530633, E-mail: ivana.miskovic@tims. edu.rs, ORCID ID 0000-0002-2588-3132

4 Srđan Milošević, Ph.D, assistant professor, Educons University, Faculty of Sport and Tourism, Radnička 30a, 21000 Novi Sad, +38121530633, E-mail: srdjan.milosevic@tims. edu.rs, ORCID ID 0000-0002-3045-5810

http://ea.bg.ac.rs 
the interest in entrepreneurship has grown in scientific circles, as well. In the Triple Helix model of innovation and entrepreneurship, the main institutions recognised were university, industry and government (Etzkowitz \& Leydesdorff, 1995), making it compatible with knowledge economy. The Quintuple Helix model (Carayannis \& Campbell, 2010) emphasizes the need for a socio-ecological transition, in which the natural environment should also be seen as a driver for development of knowledge and innovation. Innovation, as a central element of entrepreneurship, can be an answer to the environmental issues, as well. This is covered by the Agenda 21-Chapter 30 (United Nations Division for Sustainable Development, 1992).

On the other hand, tourism is one of the leading global industries. According to the estimates of the World Trade and Tourism Council (WTTC, 2019), gross domestic product GDP in the sector of tourism in 2018, including indirect and induced income, was $\$ 8.8$ billion or $10.4 \%$ of the global GDP, while the overall contribution to employment in 2018 is estimated to around 319 million (10\% of global employment). Entrepreneurship has shown its strength in aiding revitalisation of regional identities and creation of new employment possibilities (OECD, 2011). More than 99\% of all European enterprises are classified as small and medium enterprises (SME), providing $66 \%$ of jobs in the entire private sector and as many as $83 \%$ in tourism and hospitality industry. Around 95\% of accommodation and food sector in the European Union EU were classified as small businesses (UNWTO, 2013). SME are a backbone of European economy and their contribution is essential to meeting the goals of "Europe 2020: A Strategy for Smart, Sustainable and Inclusive Growth".

Entrepreneurship emphasizes the individual, environment and the entrepreneurial process itself. Each of these dimensions includes a range of specific factors (driving factors and factors of success): personal motivation, entrepreneurial climate, entrepreneurial infrastructure and support to entrepreneurship. The role of governments in stimulating and creating an adequate entrepreneurial climate is essential, with focus on people who have motives, financial means and skills to start a business.

Tourism is a field with a great degree of entrepreneurial involvement: a very intensive diversification of tourist products and services is needed to meet increased demands for new types of tourist experience. The key to success of enterprises in tourism in the future will be related to finding new sources of growth (knowledge, information), which can result in a successful business and development policy (Sundbo \& Gallouj, 2010). This also includes possibilities offered by the adoption of the concept of entrepreneurship and sustainable tourism.

This is why the process of analysing the role of entrepreneurship in sustainable tourism development is very important, as is identification of ways to strengthen entrepreneurship in tourism. The basic question of this study is: how do different actors in tourism business perceive the importance of certain entrepreneurship development factors with the greatest impact on sustainable tourism in Vojvodina?

Factors of development in tourism and, particularly, in sustainable tourism, are heterogeneous, appear in several different forms (activity, impact, process, etc.) and 
can have a positive/stimulating or negative/limiting effect. There is a large number of papers and case studies that deal with the problem of entrepreneurship development, so overviews of literature contain numerous factors that are integral parts of various models, such as the Timmons' model, GEM model, Carol Moore's model, Buhalis \& Costa model, Gartner's model, Morris \& Lewis model, the triple and quadruple helix model, etc. (Škrbić, Mišković, Milošević, \& Nešić, 2019). All of these models recognise and define the factors and their items that generally affect the development of entrepreneurship, regardless of specific area and activity. However, seeing as tourism is a complicated and complex field, very dynamic in terms of market and innovations, with a markedly specific resource basis, there is a need for an additional deeper analysis of factors and items that exhibit their specific effect primarily in the part of development of tourism entrepreneurship, taking into account the principles of sustainable development.

\section{Method}

This research was realised as an empirical study aimed at identifying levels of perception of certain factors that are interlinked and can affect the processes of development of entrepreneurship in Vojvodina's tourism, from the perspective of different tourism actors in local communities.

The sample of the research entity was composed of 34 respondents, who were differentiated (as a part of research subsampling) into representatives of two types of acting in tourism: (1) active, successful entrepreneurs in Vojvodina's tourism $(\mathrm{N}=20)$ and (2) representatives of the bodies of local communities who are authorised to represent the field of tourism in local self-governments $(\mathrm{N}=14)$.

All respondents live and work in the territory of Vojvodina and during their selection, care was taken regarding the representation of Vojvodina municipalities at varying degrees of development (from degrees I to IV of economic development),

According to the methodological character, the empirical part of the study was formatted using the Survay method. The basic research instrument (used to estimate the respondents' perception of importance/impact of certain factors that could be significant for business success and development of entrepreneurship in Vojvodina's tourism) was a questionnaire. Its construct was based on the factor models of entrepreneurship (Kayne, 2000; Lordkipanidze, Brezet, \& Backman, 2005), amended and adapted with item entries which can be deemed correspondent with particularities of the tourism environment of the AP of Vojvodina. The content of the instrument included a total of eight factors, which some of the research conducted so far (Morris \& Lewis, 1995; Buhalis \& Costa, 2006; Amorós \& Bosma, 2013) proved to be dominant in terms of entrepreneurship development, and which can, theory-wise, be applicatively related with the development of entrepreneurship in Vojvodina's tourism (Škrbić, Mišković, Milošević, \& Nešić, 2019). Those eight hypothetical factors, as basic research variables, included a necessary number of item indicators shown in Table 1. 
Table 1. Overview of factors and item indicators

\begin{tabular}{|l|l|}
\hline Factors & Item indicators \\
\hline Finances & $\begin{array}{l}\text { Grants, Benefits, Subsidised loans, Guarantee funds, Donations, Own } \\
\text { finances }\end{array}$ \\
\hline Education & $\begin{array}{l}\text { Formal education, Informal education, Business incubators, Knowledge } \\
\text { transfer, Business experience }\end{array}$ \\
\hline Partnership & $\begin{array}{l}\text { Availability of information, Cooperation with customers, Marketing } \\
\text { approach, Interest associations, Cooperation with state }\end{array}$ \\
\hline Personal traits & $\begin{array}{l}\text { Personal traits of the entrepreneur, Family support, Family business, } \\
\text { Readiness to take risk, Work experience }\end{array}$ \\
\hline State policies & $\begin{array}{l}\text { Company registration, Financial levies, Bribery and corruption, Property } \\
\text { relations, Grey economy, State administration, Influence of politics }\end{array}$ \\
\hline Market strategy & $\begin{array}{l}\text { Needs of tourists, Quality of the tourist product, Demand for tourist products, } \\
\text { Work force, Promotion and marketing }\end{array}$ \\
\hline Local community & $\begin{array}{l}\text { Attitude towards entrepreneurship, Sex and age barriers, Environment, } \\
\text { Quality of life, Tourism development plans, Trust }\end{array}$ \\
\hline $\begin{array}{l}\text { Resources and } \\
\text { infrastructure }\end{array}$ & $\begin{array}{l}\text { Tourist attractions, Intangible tourist values, General infrastructure, Tourist } \\
\text { infrastructure, Tourist suprastructure }\end{array}$ \\
\hline
\end{tabular}

Source: Authors research

The respondents' answers had the form of a rating on a value scale (a five-point scale of the Likert type) in which the numeric value of 1 (one) signified the lowest level of impact of an indicator, with 5 (five) having the highest level of impact/significance.

As a basis of quantitative analysis of empirical data of the applied statistical procedure, representative measures of central tendency and measures of variability were calculated - arithmetic mean (Mean), standard deviation (Std. Dev.) and frequency distribution. For testing the significance of differences between scalar averages calculated for the subsampled respondent categories, one-factor analysis of variance was applied (One Way ANOVA). All statistical inferences were performed with the significance level of $0.05(p<.05)$.

\section{Results}

Distributions of the respondents' answers, overall, indicate that the given factors that may have an impact on the development of entrepreneurship in tourism are recognised as clear existing determinants. However, scalar averages indicate that actors in tourism rate their role as relatively low in their immediate environment, seeing as they range in intensity from low to moderate significance $(1.64-3.52)$. In terms of their distribution on the value scale, it is possible, conditionally, to define the hierarchy of manifestation, where it is observable that respondents attach importance to the following factors: 1) Education (3.52), 2) Partnership (3.31) and 3) Personal traits of the entrepreneur (2.99). At the (conditionally) second level of importance there are: 4) Market strategy (2.31), 5) Finances (2.17) and 6) Resources and infrastructure (2.06); while the third level of importance is formed by: 7) State policy (1.80) and 8) Local community (1.64) (Table 2).

The importance of certain factors can be additionally complemented by the results of estimates of certain item indicators which clearly direct the respondents' attention 
to those determinants that are most important for development of entrepreneurship in tourism. Thus, for example, the need perceived as the most intensive is that for the education of entrepreneurs through the processes of informal (4.53) and formal education (3.74), as well as entrepreneur's business experience (3.82). On the other hand, the "weakest link" in factors of development, as perceived by tourism actors in Vojvodina, is the capacity of their local community, especially: Environment (1.21), the quality of life in it (1.53), but also barriers of sex/age that can be recognised in everyday social life (1.35). The state policy towards the sector of tourism has also been recognised as one of the more problematic factors that can hinder the development of entrepreneurship in tourism, especially taking into account the indicators: grey economy (1.24), property relations (1.35), financial levies (1.50), influence of politics (1.59), etc. (Table 2).

Table 2. Factor distribution and scalar averages (sample total)

\begin{tabular}{|c|c|c|c|c|}
\hline Factor & Mean & Std. Dev. & Item indicator of the factor & Mean \\
\hline \multirow{6}{*}{ Finances } & \multirow{6}{*}{2.17} & \multirow{6}{*}{0.246} & Grants & 2.59 \\
\hline & & & Benefits & 1.38 \\
\hline & & & Subsidised loans & 2.41 \\
\hline & & & Guarantee funds & 1.24 \\
\hline & & & Funds & 1.97 \\
\hline & & & Own finances & 3.14 \\
\hline \multirow{5}{*}{ Education } & \multirow{5}{*}{3.52} & \multirow{5}{*}{0.526} & Formal education & 3.74 \\
\hline & & & Informal education & 4.53 \\
\hline & & & Business incubators & 2.29 \\
\hline & & & Knowledge transfer & 3.24 \\
\hline & & & Business experience & 3.82 \\
\hline \multirow{5}{*}{ Partnership } & \multirow{5}{*}{3.31} & \multirow{5}{*}{0.320} & Availability of information & 3.59 \\
\hline & & & Cooperation with customers & 3.74 \\
\hline & & & Marketing approach & 2.00 \\
\hline & & & Interest associations & 2.82 \\
\hline & & & Cooperation with state & 4.38 \\
\hline \multirow{5}{*}{ Personal traits } & \multirow{5}{*}{2.99} & \multirow{5}{*}{1.067} & Personal traits of the entrepreneur & 3.09 \\
\hline & & & Family support & 3.85 \\
\hline & & & Family business & 2.82 \\
\hline & & & Readiness to take the risk & 2.12 \\
\hline & & & Work experience & 3.06 \\
\hline \multirow{7}{*}{ State policy } & \multirow{7}{*}{1.80} & \multirow{7}{*}{0.404} & Company registration & 2.38 \\
\hline & & & Financial levies & 1.50 \\
\hline & & & Bribery and corruption & 2.18 \\
\hline & & & \begin{tabular}{|l|} 
Property relations \\
\end{tabular} & 1.35 \\
\hline & & & Grey economy & 1.24 \\
\hline & & & \begin{tabular}{|l|} 
State administration \\
\end{tabular} & 2.38 \\
\hline & & & Influence of politics & 1.59 \\
\hline
\end{tabular}




\begin{tabular}{|c|c|c|c|c|}
\hline Factor & Mean & Std. Dev. & Item indicator of the factor & Mean \\
\hline \multirow{5}{*}{ Marketing strategy } & \multirow{5}{*}{2.31} & \multirow{5}{*}{0.766} & Tourists' needs & 2.76 \\
\hline & & & Quality of the tourist product & 2.32 \\
\hline & & & Demand for tourist products & 1.97 \\
\hline & & & Work force & 1.76 \\
\hline & & & Promotion and marketing & 2.71 \\
\hline \multirow{6}{*}{ Local community } & \multirow{6}{*}{1.64} & \multirow{6}{*}{0.285} & Attitude towards entrepreneurship & 2.21 \\
\hline & & & Sex and age barriers & 1.35 \\
\hline & & & \begin{tabular}{|l|} 
Environment \\
\end{tabular} & 1.21 \\
\hline & & & Quality of life & 1.53 \\
\hline & & & Plans for development of tourism & 2.18 \\
\hline & & & Trust & 1.38 \\
\hline \multirow{5}{*}{ Resources and infrastructure } & \multirow{5}{*}{2.06} & \multirow{5}{*}{0.377} & Tourist attractions & 2.38 \\
\hline & & & Intangible tourism resources & 1.97 \\
\hline & & & General infrastructure & 1.88 \\
\hline & & & Tourist infrastructure & 2.21 \\
\hline & & & Tourist suprastructure & 1.88 \\
\hline
\end{tabular}

Source: Authors research

In the context of analysis of distribution of respondents' answers based on the subsample to which they belong, certain differences were observed, largely having statistical significance, as well. In terms of hierarchical ranking of factor significance, the following distribution was observed in the entrepreneur subsample: 1) Education (3.86), 2) Personal traits of the entrepreneur (3.79), 3) Partnership (3.18), 4) Finances (2.18), 5) State policy (2.09), 6) Resources (1.92), 7) Marketing strategy (1.77) and 8) Local community. With the subsample of the representatives of the local selfgovernment (RLS) hierarchical distributions can be represented in the following way: 1) Partnership (3.49), Marketing strategy (3.07), 3) Education (3.04), Resources (2.27), 5) Finances (2.14), 6) Personal traits of the entrepreneur (1.84), 7) Local community (1.73) and 8) State policy (1.40) (Table 2).

By analysing the values of statistical significance of factors between subsamples, it can be observed that they are within the range of high significance level - Education $($ Sig. =0.000), Partnership (Sig.=0.004), Personal traits (Sig.=0.000), State policy (Sig. =0.000), Marketing strategy (Sig.=0.000), Resources and infrastructure (Sig. $=0.000)$. It is only in the factors of Finances and Local community that there are no statistically significant differences between subsamples, which can be observed from the values of their scalar averages (Table 3 ).

Table 3. Distribution of factors and scalar averages - subsamples

\begin{tabular}{|l|c|c|c|c|c|c|c|}
\hline \multicolumn{1}{|c|}{ Factor } & $\mathbf{m}$ & $\begin{array}{c}\text { Entrepreneurs } \\
(\mathbf{m})\end{array}$ & Rank & $\begin{array}{c}\text { RLS } \\
(\mathbf{m})\end{array}$ & Rank & $\boldsymbol{F}$ & Sig. \\
\hline FINANCES & 2.17 & 2.18 & 4 & 2.14 & 5 & .217 & .644 \\
\hline EDUCATION & 3.52 & 3.86 & $\mathbf{1}$ & 3.04 & 3 & 48.578 & $\mathbf{. 0 0 0}$ \\
\hline
\end{tabular}




\begin{tabular}{|l|c|c|c|c|c|c|c|}
\hline \multicolumn{1}{|c|}{ Factor } & $\mathbf{m}$ & $\begin{array}{c}\text { Entrepreneurs } \\
(\mathbf{m})\end{array}$ & Rank & $\begin{array}{c}\text { RLS } \\
(\mathbf{m})\end{array}$ & Rank & F & Sig. \\
\hline PARTNERSHIP & 3.31 & 3.18 & 3 & 3.49 & $\mathbf{1}$ & 9.440 & $\mathbf{. 0 0 4}$ \\
\hline PERSONAL TRAITS & 2.99 & 3.79 & $\mathbf{2}$ & 1.84 & 6 & 156.794 & $\mathbf{. 0 0 0}$ \\
\hline STTE POLICY & 1.80 & 2.09 & 5 & 1.40 & 8 & 83.490 & $\mathbf{. 0 0 0}$ \\
\hline MARKETING STRATEGY & 2.31 & 1.77 & 7 & 3.07 & $\mathbf{2}$ & 82.191 & $\mathbf{. 0 0 0}$ \\
\hline LOCAL COMMUNITY & 1.64 & 1.58 & 8 & 1.73 & 7 & 2.146 & .153 \\
\hline $\begin{array}{l}\text { RESOURCES AND } \\
\text { INFRASTRUCTURE }\end{array}$ & 2.06 & 1.92 & 6 & 2.27 & 4 & 8.843 & $\mathbf{. 0 0 6}$ \\
\hline
\end{tabular}

Source: Authors research

\section{Discussion}

Education is recognised as a factor with the greatest level of influence. Educational process previously undergone by generations of now able-bodied people has not, (at least not significantly) focused on entrepreneurship as an employment option. Until recently, entrepreneurship, as a subject, was not in the curricula of institutions of elementary, high school and higher education, so generations of pupils and students did not, upon graduating, turn to exploring entrepreneurial ideas and their market realisation, but were streamlined towards state firms or state jobs, as a safe option of stable income and employment. Hence, their children did not have the opportunity to learn about entrepreneurship from the examples of their immediate environment, either. It is thus not surprising that Education features as a factor with the greatest scalar average. Taking into account the current tempo of life, the lack of time and the rapidity of market changes, it is unsurprising that, according to the respondents' opinion, the greatest importance is that of Informal education, which can offer the missing knowledge and skills in a short span of time to all generations of potential entrepreneurs. Considering the fact that, in terms of importance, the following two item indicators are Business experience and Formal education, one can observe the advantage of introducing a system of dual education, which will give both a theoretical basis and a practical business experience. A low rank of the item indicator of Business incubator can be explained only by the fact that the broad public is still not familiar with the notion of business incubators, i.e. their role and function. Business incubators are an instrument that selects potential entrepreneurial ideas and offers the necessary administrative, consulting and logistic support in the initial and most sensitive phases of development of the entrepreneurial idea and they do so in perhaps the best and the fastest way (Bošković, Andrić, \& Tomić, 2011). A number of more recent studies underlines the need to support entrepreneurship. Especially from the perspective of the identified factor - gender representation in the overall population of entrepreneurs in the rural areas of the AP of Vojvodina (a significantly higher ratio of men), low level of education being recognised as one of the primary causes of such a state (Munitlak Ivanović, Mitić, \& Raspopović, 2016). 
In view of the above, primary activities should relate to: (1) non-formal education in order to develop entrepreneurship; (2) recognizing the role of the cluster; (3) inclusion of vulnerable social groups in entrepreneurship; (4) implementation of entrepreneurial activities in all levels of education. Implementers of education should be: formal educational institutions, NGO's, clusters, local goverments, Regional Development Agencies, Destination Management Organizations (DMO's), Tourism Organizations, and all those who aim to develop entrepreneurship in tourism and local development.

The high positioning of the Partnership factor by the representatives of the local self-government and tourism entrepreneurs points to the awareness of the existence of a value chain in which every link is equally important and in which all activities must be systematically planned and led in a coordinated manner, in the function of a common interest. In favour of this are the highly-rated item indicators of Cooperation with customers and Availability of information, as elements that are essential for an unhindered functioning of the value chain. The highest-rated item indicator of Cooperation with the state indicates a necessity of a proactive role by the state through its institutions and representatives. The top-down development principle is still assumed by entrepreneurs in tourism, but also by the representatives of the local selfgovernment, as the state is still expected to be the one to take the first step. The lowestrated item indicator of Marketing approach indicates an underdeveloped awareness of market as a very dynamic regulatory factor, especially in the field of tourism and that the product, regardless of how high in quality it might be, is not going to sell itself. The fact that needs to be emphasized here is that building a quality integral tourist product requires a functional cooperation of all participants of the value chain and that only joint marketing approaches in the form of a quality integral tourist product stand a chance on the market. It can also be concluded that there is low awareness of the fact that the market offers two-way communication in the form of essential feedback information which can significantly affect the business success of an entrepreneurial undertaking. This is corroborated by some earlier research that emphasizes the need to improve management processes, marketing skills and knowledge in the field of communication, so they could have a more intensive role in the development of entrepreneurship in Vojvodina (Bošković, Andrić, \& Tomić, 2011).

When it comes to the factor of Personal traits of the entrepreneur, one must take into account different aspects of perception of importance of this factor: entrepreneurs perceive this factor directly, from personal experience and through personal examples, while the representatives of the local community perceive this factor indirectly, without personal experience, so it is only real that there is a statistically significant difference between these two subsamples. Family support is the most important item indicator. The obtained result can be related to the educational structure, in the sense that an unfavourable educational structure leads to a lower degree of security and self-confidence, increasing the need to rely on people from close environment in everyday entrepreneurial activities and decision-making processes. This is corroborated by the results of previous research dealing with internal motives for commencing entrepreneurship (with entrepreneurs who 
became ones out of necessity and were forced to employ themselves, they indicate that these entrepreneurs, in addition to poorer business results, on average, also have a smaller capital; they are, on average, older, lacking business skills and have a lower potential for recognising market circumstances, as well as a strong need to rely on people from their immediate environment) (Bobera, Marić, \& Leković, 2015) (Škrbić, 2016).

These are followed by Personal traits of the entrepreneur, i.e. his/her Work experience up to the point. The item indicator of Family business is not highly ranked, which correlates with the timespan of the entrepreneurial culture and tradition in any one given area, i.e. there are few family firms engaging in tourism in the territory of the AP of Vojvodina with a longer tradition that could represent a direct entrepreneurial role model for younger generations. If parents or other close family members are entrepreneurs, there are significantly higher chances of children becoming entrepreneurs in the future, as well (Rakićević, Omerbegović Bijelović, \& Ljamić-Ivanović, 2015). However, in the early phases of development of sustainable tourism in Vojvodina in the entrepreneurial form, the effects of engaging in this field are not visible, which causes a low level of motivation by the population to engage in this field (Bošković, Andrić, \& Tomić, 2011).

Market strategy, as a factor, was represented by a relatively stable scalar average, overall. It is worth noticing here that the representatives of the local self-government rated this factor as far more important (rank 2) in relation to the significance attributed to this factor by entrepreneurs in tourism (rank 7). This can point to the need for additional education of entrepreneurs, since creating strategic plans that affect the quality of tourist products in accordance with the needs and demands of the market is one of the foundations of the current business practices.

Recognising the Needs of tourists, along with Promotion and marketing and Quality of the tourist product are item indicators which, according to the respondents' opinion, are the most important ones; i.e. they are the essential elements for successfully creating an integral tourist product. In addition to this, the obtained results confirm that the various forms of numerous trainings that have been realised in Vojvodina in recent years have increased the level of knowledge on creating a tourist product, even though the application of this knowledge is yet to yield significant results in practice.

In terms of ranking of the Finances factor, no statistically significant differences between subsamples were observed. It can thus be inferred that they do not represent the primary cause of slower development of entrepreneurship in tourism, although a commonly heard argument is precisely that of insufficient finances being the first and foremost reason for the lack of realisation in this field. Analysing the activities carried out so far by the provincial and republic-level authorities indicates that sources of financing directed towards developing tourism and stimulating entrepreneurial activities and capacities have existed. The AP of Vojvodina has recently been recognising the importance of developing tourism in Vojvodina, financially supporting the improvement of capacities of certain types of tourism (Njegovan, Demirović, \& Radović, 2015). In 
2018, the Provincial Secretariat for Economy and Tourism subsidised a part of the loan granted by the Development Fund of the AP of Vojvodina, the purpose of which was advancement of tourism (Pokrajinska vlada AP Vojvodine, 2018).

In the measurement of item indicators, the highest rated indicators were those that concerned providing financial resources not conditioned by payments of high interest rates (Own finances, Grants and Subsidised loans). Guarantee funds is an item indicator that was rated lowest. Just like with Business incubators, it is very likely that the lack of knowledge and information on the advantages of guarantee funds conditioned such a low value. It should be mentioned here that some studies emphasize the particular sensitivity of female population with respect to the lack of financial resources and in the context of starting business activities in rural areas (Munitlak Ivanović, Mitić, \& Raspopović, 2016).

An important factor limiting the development of tourism is the lack of adequate support services and good infrastructure, such as transport, good roads, telecommunications networks, financial and other services, wastewater treatment facilities and good tourist suprastructure (Centar za konkurentnost, 2012). Observing the context of Vojvodina, it can be inferred that the problems of infrastructure are not a burden on the development of tourism, but also that the tourist infrastructure and suprastructure are often a problem. A great number of places in Vojvodina do not have adequate accommodation capacities, both from the aspect of quantity and the aspect of quality and market demands. The lack of accommodation capacities still hinders the development of certain forms of tourism that require accommodating a larger number of visitors at the same time. Certain tourist localities and attractions are present in the tourism market, but not in the form of a tourist product or a part thereof, but only in the form of a notice of their existence, without tourist valorisation and market concretization. This indicates that tourism resources and not tourism products are often promoted. The item indicator of Intangible tourism resources was rated as below average, which is opposed to the prevalent opinion that one of the main tourist assets of Vojvodina is its multiculturality, its way of life, events, etc. Traditionally, Vojvodina has been perceived as an agricultural region in which tourism is not a priority, unlike some other regions and destinations (Western Serbia, Kopaonik, Zlatibor, Vrnjačka Banja, etc.). There is a rich resource foundation for creating a quality tourist product in Vojvodina and the next phase is strategic creation of capacities that will transform resources into a tourist product.

In this study, state policies were not found to be a highly influential factor. Still, previous experience points to an important role of the state in developing tourism in the territory of Vojvodina (Njegovan, Demirović, \& Radović, 2015). The state, at the republic, provincial and local levels, should use its policies and instruments to give incentive to the development of sustainable tourism through entrepreneurial initiatives. The specificity of tourism, as an industry with a highly multiplicative effect, is that it opens the possibilities to improve the quality of life of the local populace. Achieving the desired effects would also entail strategically planned and coordinated activities, and embracing public-private partnerships as a means to pursue common interests. 


\section{Conclusion}

Taking into account the results obtained in the context of specificity of environment in the AP of Vojvodina, it can be inferred that entrepreneurs in tourism with some experience in business do not rate the factors that can affect the development of the entrepreneurial process like the representatives of local self-government do. Out of the eight assessed factors, as many as six are rated with a statistically significant difference for the subsamples observed. This result can indicate potential reasons for slower development of entrepreneurial activities in the field of tourism, as representatives of local authorities prioritise those factors that they consider to be the most important and they create incentive instruments in accordance with this, while, on the other hand, entrepreneurs find certain other factors more significant in the process of starting and developing entrepreneurial activities in tourism. This presumption was corroborated by the results obtained, seeing as they identify the factors of Education and Partnership as factors with the greatest impact. Partnership, cooperation and communication between all interested stakeholders from all three sectors (state, private and civil) are a prerequisite for creating a good strategy that will be aimed at developing sustainable tourism in Vojvodina. It is necessary to add that a proactive attitude of all sides is indispensable, as that is the only way that can yield the optimal effects.

\section{Acknowledgements}

The paper is a part of research within the project no. 142-451-2109/2019-03 - „Models of entrepreneurship development in sustainable tourism of Vojvodina", financed by the Provincial Secretariat for higher education and scientific research of the Autonomous Province of Vojvodina.

\section{Conflict of interests}

The authors declare no conflict of interest.

\section{References}

1. Amorós, J. E., \& Bosma, N. (2013). Global Entrepreneurship Monitor 2013 Global Report Fifteen Years of Assessing Entrepreneurship Across the Globe. Global Entrepreneurship Research Association: Desarrollo.

2. Ballantyne, R., Packer, J., \& Axelsen, M. (2009). Trends in tourism research. Annals of Tourism Research, 26(1), 149-52.

3. Bobera, D., Marić, S., \& Leković, B. (2015). Entrepreneurship as a consequence of external stimuli and/or internal incentives. Economic Themes 53(1), 85-103. [in Serbian: Bobera, D., Marić, S., \& Leković, B. (2015). Preduzetništvo kao posledica eksternih podsticaja i/ili internih pobuda]. 
4. Bošković, T., Andrić, N., \& Tomić, D. (2011). Human and Financial Resources Factors of Development of Rural Tourism in AP Vojvodina. The School of Business, 32-41. [in Serbian: Bošković, T., Andrić, N., \& Tomić, D. (2011). Humani i finansijski resursi- činioci razvoja ruralnog turizma u AP Vojvodini].

5. Buhalis, D., \& Costa, C. (2006). Tourism Management Dynamics. Oxford: Elsevier.

6. Carayannis, E., \& Campbell, D. (2010). Triple Helix, Quadruple Helix and Quintuple Helix and How Do Knowledge, Innovation and the Environment Relate To Each Other?: A Proposed Framework for a Trans-disciplinary Analysis of Sustainable Development and Social Ecology. International Journal of Social Ecology and Sustainable Development, 1(1), 41-69.

7. Competitiveness Center. (2012). How to Incubate Tourism Services - Collaboration of Incubators and Clusters. Novi Sad: Competitiveness Center. [in Serbian: Centar za konkurentnost. (2012). Kako inkubirati turističke usluge-saradnja inkubatora i klastera].

8. Etzkowitz, H., \& Leydesdorff, L. (1995). The Triple Helix- UniversityIndustry- Government Relations: A Laboratory For Knowledge Based Economic Development. EASST Review, 14(1), 14-19.

9. Kayne, J. (2000). Rural Entrepreneurship Initiative. Second Minnesota Academy working session (p. 8). Rochester, Minnesota: Kauffman Center for Entrepreneurial Leadershi.

10. Košić, K., Demirović, D., Pejanović, R., Lazić, L., \& Stamenković, I. (2015). Key principles of rural tourism households development strategy - case study of Vojvodina. Economics of Agriculture, 62(4), 975-988.

11. Lordkipanidze, M., Brezet, H., \& Backman, M. (2005). The entrepreneurship factor in sustainable tourism development. Journal of Cleaner Production, 13(8), $787-798$.

12. Morris, M., \& Lewis, S. (1995). The determinants of entrepreneurial activity: Implications for marketing. European Journal of Marketing, 31- 48.

13. Munitlak Ivanović, O., Mitić, P., \& Raspopović, N. (2016). Gender equality - perspectives of rural women entrepreneurship in Vojvodina, The Business Economics, 157-172. [in Serbian: Munitlak Ivanović, O., Mitić, P., \& Raspopović, N. (2016). Perspektive ruralnog ženskog preduzetništva u AP Vojvodini].

14. Njegovan, Z., Demirović, D., \& Radović, G. (2015). Managing sustainable development of rural tourism in Vojvodina, The School of Business, 68-79. [in Serbian: Njegovan, Z., Demirović, D., \& Radović, G. (2015). Upravljanje održivim razvojem ruralnog turizma u Vojvodini].

15. OECD. (2011). Measuring Green Entrepreneurship, in Entrepreneurship at a Glance 2011. OECD Publishing.

16. Page, C., \& Ateljevic, J. (2009). Tourism and Entrepreneurship: International Perspectives. Oxford: Butterworth Heinemann. 
17. Government of the Autonomous Province of Vojvodina. (2018). For tourism development in Vojvodina up to 20 million dinars for 7 years without interest. http://www.vojvodina.gov.rs [in Serbian: Pokrajinska vlada AP Vojvodine. (2018). Za razvoj turizma u Vojvodini do 20 miliona dinara na 7 godina bez kamate].

18. Rakićević, Z., Omerbegović Bijelović, J., \& Ljamić-Ivanović, B. (2015). Virtual entrepreneurship: education in support of entrepreneurial readiness of students. International Scientific Conference of IT and Business-Related Research (pp. 635641). Belgrade: Singidunum University.

19. Sundbo, J., \& Gallouj, F. (2010). Innovation as a loosely coupled system in services. International Journal of Services Technology and Management, 1(1), 15-36.

20. Škrbić, I. (2016). Entrepreneurship Development Model in the Context of Pro-poor Tourism in Rural Areas - PhD thesis. Sremska Kamenica: Educons University, Faculty of Business Economics. [in Serbian: Škrbić, I. (2016). Model razvoja preduzetništva u okviru pro-poor turizma u ruralnim sredinama - doktorska teza.].

21. Škrbić, I., Mišković, I., Milošević, S., \& Nešić, M. (2019). Entrepreneur models in function of sustainable tourism. Business economics, 81-99. [in Serbian: Škrbić, I., Mišković, I., Milošević, S., \& Nešić, M. (2019). Preduzetnički modeli u funkciji održivog turizma].

22. United Nations Division for Sustainable Development. (1992). Agenda 21, Chapter 30 - Strengthening role of bussines and industry, 30.17- Promoting responsible entrepreneurship. Rio de Janerio: United Nations Division for Sustainable Development.

23. UNWTO. (2013). Tourism Highlights, 2013 Edition. UNWTO.

24. WTTC. (2019). Worl Travel and Tourism Council Economic Impact 2018. London: WTTC. 
